DOI: https://doi.org/10.15688/jvolsu3.2017.4.1

UDC 332.1:338.2

LBC 65.04:65.05:65.9(2Poc...)

\title{
ASSESSMENT OF THE TERRITORIAL AND ECONOMIC CONNECTION OF CITIES IN THE AGGLOMERATION (THE CASE OF BIG ROSTOV)
}

\author{
Elena O. Mirgorodskaya
}

Don State Technical University, Rostov-on-Don, Russian Federation

\begin{abstract}
The urban agglomeration is a complex form of municipalities association based on the potential of productive and human resources, the effects of concentration and specialization of settlements. The cities that make up agglomerations, form a special system of socio-economic interaction with each other. The existence of permanent and stable links between municipalities within the urban agglomeration is an important condition for its existence and development. Theoretical and practical problems of cities' agglomeration interaction are at the center of attention of many Russian and foreign scientists. Analysis of the experience of studying agglomerations is the basis of the present research. However, it should be noted that to date there is no well-founded, systematic approach to assessing the degree of cohesion of the cities that make up the agglomeration, and there is no synthetic model for managing the socio-economic development of urban agglomerations, applicable in Russian conditions.

The article describes five methods allowing to identify and to assess the degree of such territorial and economic cohesion: spatial concentration based on the Theil index; investigating the regional contact-gravitational environment of the territory; integrated assessment of the variation of indicators of municipalities based on the Gini index; delimitation of agglomeration based on transport linkages between cities; investigating the interaction of cities as economic entities.

The object of the study is represented by the Rostov agglomeration (Big Rostov) as the largest and most developed one in the South of Russia. To analyze the degree of territorial and economic cohesion and spatial concentration of the cities of the Rostov agglomeration, a set of methods and indicators was used. They allowed differentiating the cities that make up the agglomeration, according to the degree of their attraction by the nucleus. Based on the totality of the investigated quantitative parameters, a rating and typology of the cities of the reference territory of the Rostov agglomeration was carried out in terms of the degree of interaction with Rostov-on-Don as its center. The analysis of the process of agglomeration gravity of cities and its separate vectors is carried out, directions of their perspective development are determined, proceeding from their established connection of settlements.
\end{abstract}

Key words: agglomeration, Rostov agglomeration, city connectivity, socio-economic interaction, transport accessibility, city rating, typology of cities.

УДК 332.1:338.2

ББК 65.04:65.05:65.9(2Рoc...)

\section{ОЦЕНКА ТЕРРИТОРИАЛЬНО-ЭКОНОМИЧЕСКОЙ СВЯЗАННОСТИ ГОРОДОВ В АГЛОМЕРАЦИИ (НА ПРИМЕРЕ БОЛЬШОГО РОСТОВА)}

\author{
Елена Олеговна Миргородская
}

Донской государственный технический университет, г. Ростов-на-Дону, Российская Федерация 
Аннотация. Городская агломерация является сложной формой объединения муниципальных образований на основе имеющегося потенциала производственных и человеческих ресурсов, эффектов концентрации и специализации поселений. Города, входящие в состав агломераций, образуют особую систему социально-экономического взаимодействия друг с другом. Наличие постоянных и устойчивых связей между муниципалитетами в составе городской агломерации - важное условие ее существования и развития. Теоретические и практические проблемы агломерационного взаимодействия городов находятся в центре внимания многих российских и зарубежных ученых. Анализ опыта изучения агломераций положен в основу данной работы. Однако необходимо констатировать, что до настоящего времени отсутствует обоснованный систематизированный подход к оценке степени связанности городов, входящих в состав агломерации, и синтетическая модель управления социально-экономическим развитием городских агломераций, применимая в российских условиях.

В данном исследовании рассматривалось пять методов, позволяющих выявить и оценить степень подобной территориально-экономической связанности: пространственной концентрации на основе индекса Тейла; исследования региональной контактно-гравитационной среды территории; комплексной оценки вариации показателей муниципальных образований на основе индекса Джини; делимитации агломерации на основе транспортных взаимосвязей между городами; исследования взаимодействия городов как хозяйствующих субъектов.

Объектом исследования выступала Ростовская агломерация (Большой Ростов) как наиболее крупная и развитая на Юге России. Для анализа степени территориально-экономической связанности и пространственной концентрации городов Ростовской агломерации использовался комплекс методов и индикаторов, позволивший дифференцировать города, входящие в состав агломерации, по степени их «притяжения» ядром. На основе совокупности исследованных количественных параметров был проведен рейтинг и типология городов опорной территории Ростовской агломерации по степени взаимодействия с Ростовом-на-Дону как ее центром. Дан анализ процесса агломерационной гравитации городов и ее отдельных векторов, определены направления их перспективного развития, исходя их сложившейся связанности поселений.

Ключевые слова: агломерация, Ростовская агломерация, связанность городов, социально-экономическое взаимодействие, транспортная доступность, рейтинг городов, типология городов.

В качестве одной из основных концепций расселения в Российской Федерации выдвигают формирование и развитие городских агломераций как центров инновационного экономического роста и социального развития. Агломерационная форма концентрации населения и хозяйства соответствует условиям нашей страны с ее территориальным размахом, многонациональностью, разнообразием природных и иных ресурсов и контрастностью социально-экономических условий развития. При целенаправленном подходе агломерации могут выступить средством решения острых и крупных проблем регионов, становясь своеобразными точками опережающего развития, выполняя роль «скрепления» территории на основе совокупности экономических, бытовых, транспортных, культурных, образовательных и социальных связей. В то же время развитию агломераций, заключающемуся в их территориальном росте и качественных преобразованиях пространственной структуры и функций, сопутствуют определенные проблемы, связанные с недостатком транспортных коммуникаций, высоким уровнем износа инфра- структуры и жилищного фонда, ухудшением экологической ситуации, нерешенностью вопросов правового регулирования взаимоотношений муниципальных образований, входящих в агломерации, а следовательно, конфликтными ситуациями между ними в различных сферах деятельности [8, с. 95]. Это связано в первую очередь с отсутствием законодательно закрепленного феномена «агломерация», что не позволяет четко разграничить полномочия муниципальных образований при территориальном планировании в процессе управления агломерационным процессом. Кроме того, существуют проблемы в рамках межбюджетных отношений, что приводит к конкурентному режиму за бюджетные федеральные ресурсы. Именно поэтому на сегодняшний день в России наблюдается практическое отсутствие эффективного опыта функционирования городских агломераций.

Развитие агломерации предполагает взаимосвязанность городов, определенное пространственное единство. Социально-экономическая взаимосвязанность городов является одним из важнейших показателей развития 
городских агломераций. Оно проявляется в формировании, усложнении и изменении векторов взаимовлияния муниципальных образований в составе агломерации друг на друга в процессе хозяйственной деятельности. Так, для агломераций характерны следующие тенденции: последовательное смещение населения от внутренних колец агломерации к внешним, сильное развитие маятниковой миграции, развитие городов-спутников.

Рассмотрение феномена взаимосвязанности городов является значимым в контексте понимания процессов формирования региональных каркасов и пространственно-экономических сетей, а также позволяет сформировать научную основу для выявления основных проблем в развитии регионального пространства и совершенствования региональной пространственно-экономической политики в отношении городских поселений.

При этом следует отметить, что как такового понятия «агломерационная взаимосвязанность городов» в региональной социальноэкономической системе до сих пор в науке не сформировалось. С одной стороны, это связано с фрагментарным характером региональных исследований в данной предметной области, а с другой - с крайне явным отрывом теоретических предположений от практики трансформации экономической реальности в городском пространстве. По сути дела, имеющиеся теоретические подходы в виде теории опорного каркаса региона и теории пространственно-экономических сетей остаются лишь концептуальными конструктами, редко использующимися при разработке региональной пространственно-экономической политики.

По нашему же мнению, в них заложен существенный эвристический и прикладной потенциал, позволяющий с позиций пространственно-экономической структуры объяснить асимметричный, несбалансированный характер, уяснить причины и спрогнозировать тенденции трансформации центров социально-экономической активности населения в регионе.

Взаимосвязанность городов в агломерации как особый пространственно-экономический механизм предполагает выделение определенных контактных процессов, направленных на создание территориально-экономического единства, общности в пространстве. Такие кон- тактные процессы должны обладать рядом следующих признаков, которые определяют пространственно-экономические особенности в организации и размещении элементов городского агломерационного пространства:

- территориальная смежность взаимосвязанных городов (близость контактирующих городов в рамках административно-территориальной иерархии или их соподчиненность);

- функциональная смежность городов (территории, имеющие идентичную экономическую специализацию, в большей степени комплементарны друг другу, нежели локалитеты с иным экономическим профилем);

- расстояние между городами (географические характеристики);

- уровень развития региональной транспортно-коммуникационной инфраструктуры (это обусловливает «включенность» городов в региональные урбанизационные каркасы, минимизирует степень пространственно-экономической обособленности);

- пространственно-экономическая взаимосвязь города-спутника с городом-центром;

- особенности миграционных процессов в рамках системы пространство - время (миграционные потоки определяют открытость и контактность городской экономики, ее комплементарные и диффузионные свойства).

Итак, в первую очередь это касается реализации совместных социально-экономических проектов в рамках межмуниципального взаимодействия. Данные проекты могут быть ориентированы на реализацию программных мероприятий в рамках социально-экономического развития всех городов, входящих в агломерацию. Во-вторых, это осуществление мероприятий по инфраструктурной обеспеченности агломерации (транспортной, информационной, коммунальной и других видов инфраструктуры городов). В-третьих, консолидация конкурентных преимуществ на основе объединения потенциалов городского развития, что позволит сформировать единый бренд агломерации с выходом на национальный рынок. В-четвертых, это формирование совместного рыночного пространства городов за счет создания особых торговых зон, вынесенных в межгородское пригородное пространство. B-пятых, формирование общих пространственных кластерных образований, особых эконо- 
мических зон, направленных на ускорение территориального развития на основе привлечения инвестиций и использования инновационных технологий для производства высокотехнологичной, конкурентоспособной продукции.

Для осмысления пространственно-экономической цельности агломерации и взаимосвязанности городов в ее составе существует ряд методик, позволяющих выявить и оценить степень подобной территориально-экономической связанности, главными из которых являются:

1. Метод пространственной концентрации на основе индекса А. Тейла.

2. Метод исследования региональной контактно-гравитационной среды территории (РКГС).

3. Метод комплексной оценки вариации показателей МО на основе индекса Джини.

4. Метод делимитации агломерации на основе транспортных взаимосвязей между городами.

5. Метод исследования взаимодействия городов как хозяйствующих субъектов [2; 3].

Каждый из этих методов имеет свои преимущества и недостатки, обусловливающие возможности его фактического применения на практике при изучении конкретных городских агломераций.

Так, к примеру, метод пространственной концентрации на основе индекса Тейла является сравнительно новым для отечественных исследователей, поскольку методологическая основа его использования была заложена лишь в последние годы в связи с приходом в нашу страну такого направления, как новая экономическая география [5, с. 250]. Объектом анализа при этом выступают крупные муниципальные образования (МО), расположенные на общей, единой (в природном и социальноэкономическом отношении) либо территориально сближенной территории, а сущность метода заключается в определении степени равномерности (диспропорций) в локализации МО. Хотя изначально индекс Тейла применялся для выявления неравенства в распределении доходов населения, со временем преимущества данного метода как основы исследования взаимодействия городов стали очевидны в научных кругах, в том числе и в отечественных. К примеру, данный метод был использован Е.А. Коломак при изучении агломе- рационных эффектов на территории Новосибирской области [5]. Отличительными особенностями рассматриваемого метода являются его наглядность и более подробная детализация процессов, происходящих внутри агломерации, в отличие от методов исследования, основанных на индексе Джини [7].

Метод региональной контактно-гравитационной среды территории (РКГС) выступает одной из форм исследования агломерации с позиции теории пространственных форм контакта городов. Целесообразность применения данного подхода в качестве основы исследования механизма взаимодействия городов обусловлена необходимостью такого концептуального конструкта, который объединяет в себе основные структурные компоненты и взаимосвязи между ними и позволяет понять предпосылки межгородского взаимодействия. Это же в свою очередь продиктовано тем, что имеющиеся научные теории уже не в полной мере объясняют современные причины, особенности и последствия взаимодействия городов, входящих в агломерации. Расчет показателя РКГС производится по следующей формуле:

$$
I_{i j}=\frac{A_{j} \times p_{i} \times p_{j}}{D_{i j}^{2}} \times K_{i f},
$$

где $I_{i j}$ - объем взаимодействия между центром агломерации и городом; $A_{j}$ - показатель «сгущенности» экономического пространства города (отношение плотности предприятий в центре агломерации к предприятиям города); $p_{i}$ - численность населения в центре агломерации; $p_{j}$ - численность населения в конкретном городе; $D_{i j}^{2}$ - расстояние между центром и городом; $K_{i f}-$ поправочный коэффициент.

Поправочный коэффициент $\left(K_{i f}\right)$ устанавливается по соответствующей шкале (см. табл. 1), исходя из величины показателя плотности ведомственных и муниципальных автодорог с твердым покрытием в соответствующем городе, и имеет формулу:

$$
P L_{j}=\frac{S}{V},
$$

где $P L_{j}-$ плотность ведомственных и муниципальных автодорог с твердым покрытием в $j$-м городе; $S$ - территория (кв. км) $j$-го города (района); $V$ - протяженность ведомственных и муниципальных автодорог с твердым покрытием в $j$-м городе (районе), км. 


\section{Определение величины поправочного коэффициента в модели РКГС}

\begin{tabular}{|c|c|c|c|c|c|}
\hline \multirow{2}{*}{ Величина $P L_{j}$} & \multicolumn{5}{|c|}{ Процентов от максимальной величины } \\
\cline { 2 - 6 } & $0-20$ & $20-40$ & $40-60$ & $60-80$ & $80-100$ \\
\hline$K_{i f}$ & 1 & 1,25 & 1,5 & 1,75 & 2 \\
\hline
\end{tabular}

Примечание. Составлено по данным: [6, с. 132].

Подобный подход способен обеспечить выделение главных элементов взаимодействия между городами, выявить точки роста и драйверы экономического развития территории. Важным достоинством использования метода РКГС является его универсальность, благодаря чему исследователь получает возможность получить конкретную информацию о межтерриториальных контактах различного направления, генезиса и степени интенсивности взаимодействия городов внутри агломерации, не отвлекаясь на лишние детали. Таким образом, данный метод способен представить исследователю всю полноту картины, что делает его незаменимым при исследовании моноцентрических агломераций, имеющих особенности в своем административно-территориальном строении. К такому типу можно отнести и Ростовскую городскую агломерацию (Большой Ростов) - крупнейшую на Юге России с численностью населения около 1,8 млн человек.

Методология РКГС была апробирована С.И. Кутовым при исследовании взаимодействия городов как одного из составных компонентов развития регионального экономического пространства [6]. Применение метода РКГС на практике не только доказало его универсальность, но и раскрыло его широкие возможности при оценке роли каждого из городов в составе агломерации. Данное основание позволяет оценить этот метод как наиболее объективный и востребованный из всех имеющихся методик изучения характеристики агломерационного взаимодействия муниципалитетов.

Метод комплексной оценки вариации показателей на основе индекса Джини включает в себя три этапа:

1) рейтинговую оценку «по среднему месту» показателей муниципальных образований;

2) комплексную оценку по методу главных компонент;

3) расчет аналога индекса Джини.
При этом первоначально применяют систему расчета рейтинговой оценки МО агломерации «по средней величине» показателей МО (так называемому «среднему месту» в совокупности). Это позволяет интерпретировать результат в наглядной форме, то есть сразу отражает место, занимаемое объектом среди подобных ему. Затем на основе составленной рейтинговой системы проводят комплексную оценку МО по методу главных компонент.

Индекс Джини как статистический показатель, с помощью которого можно описывать характер изменения одной величины относительно изменения другой, позволяет дать оценку неравномерности распределения изучаемого признака. На практике данный метод активно используется лишь при комплексной оценке развития МО, входящих в состав укрупненных групп, к примеру, при исследовании уровня развития МО, входящих в состав одного субъекта РФ. Исследования с использованием данной методики, как отмечает C.В. Баранов, способны ответить лишь на вопрос об общем состоянии параметров развития региона. Взаимодействие отдельных городов в рамках подобной методологии исследования фактически нивелируется, что сводит на нет ее эффективность при исследовании взаимодействия городов в крупных и средних агломерациях [2, с. 50].

Поскольку агломерация представляет собой специфическую форму пространственной организации населения и экономики, концентрирующую предприятия хозяйственного комплекса, рекреационные зоны, производственную и социальную инфраструктуру, то одним из важных критериев ее исследования является транспортная доступность объектов. Оценить его позволяет метод делимитации агломерации на основе транспортных связей между городами. Данный метод выполняет существенную гносеологическую и методологическую роль, поскольку в совокупности 
природные (естественные), социально-экономические, политические и иные факторы формируют уникальный облик агломераций на отдельно взятой территории. С учетом развития мобильности трудовых ресурсов и скорости доставки грузов и пассажиров роль данного метода в региональных исследованиях еще более возрастает $[7 ; 8]$.

Концептуальные основы метода делимитации агломерации на основе транспортных взаимосвязей между городами, были заложены в нашей стране еще в середине 1970-х гг. благодаря изучению процесса образования и функционирования агломераций известным географом-урбанистом Г.М. Лаппо и формирования геоурбанистики как самостоятельного научного направления [7]. В своих трудах он подчеркивал важность транспортных связей как основного элемента определения границ агломераций [7]. Со временем эта мысль получила свое дальнейшее развитие, и на сегодняшний день анализ транспортной инфраструктуры агломерации стали рассматривать как один из основных методов изучения взаимодействия городов в границе агломерации [7; 8].

Суть метода заключается в выделении концентрических зон транспортной доступности поселений вокруг ядра агломерации. Первая, получасовая изохрона относительно границ города - это ядро агломерации; вторая одночасовая изохрона; третья - 1,5-часовая изохрона; четвертая - получасовая изохрона относительно средних и больших городов, расположенных вблизи границ агломерации, или же двухчасовая изохрона относительно города-ядра [8]. Применение данного метода нашло свое отражение в работах многих отечественных авторов в первую очередь ввиду простоты применения и наглядности [9]. Однако стоит отметить, что подобный подход при всей своей достоверности обладает довольно существенным недостатком - его нельзя применять как основной в оценке городской агломерации в разрезе отражения степени взаимодействия городов. Идеальным способом применения этого метода является включение его в комплексное исследование степени взаимодействия городов внутри агломерации.

Последним из названных выше является метод исследования взаимодействия го- родов как хозяйствующих субъектов. Этот метод также является сравнительно инновационным при изучении агломераций, хотя предпосылки для его использования возникли уже давно, поскольку те же индексы Джини и Тейла изначально использовались в маркетинге и управлении отдельными хозяйствующими субъектами, что не помешало их успешному использованию в региональных исследованиях агломерационных систем [1, c. 80]. Алгоритм применения данного метода заключается в том, что города, входящие в состав агломерации, рассматриваются как отдельные территориально-экономические субъекты, для чего производится оценка их экономического потенциала. Затем информация о каждом из городов, входящих в состав агломерации, группируется и применяется индексный анализ полученных данных с последующим построением оптимизационных моделей развития агломерации.

Достоинством данной модели является возможность рассмотрения городов с точки зрения денежных потоков, генерируемых ими за счет функционирования совокупности всех экономических субъектов, действующих на их территории. Главным недостатком, перекрывающим практическое применение данной методики при изучении крупных агломераций, является несовершенство модели, которая работает лишь при оценке экономического потенциала малых и средних городов, входящих в состав агломерации, а также необходимость запроса расширенных статистических данных по каждому из городов.

Итак, следует агрегировать рассмотренные методы исследования агломерационного взаимодействия городов (см. табл. 2), выделив их преимущества и недостатки, а также возможности применения для оценки Ростовской агломерации, выступающей эмпирическим объектом нашего исследования [4].

Исходя из имеющейся базы эмпирических данных из рассмотренной совокупности методов наиболее целесообразными и приемлемыми при изучении Ростовской агломерации, на наш взгляд, являются два - метод исследования РКГС и метод делимитации агломерации на основе транспортных взаимосвязей между городами. 
Методы анализа агломерационного взаимодействия городов

\begin{tabular}{|c|c|c|c|}
\hline $\begin{array}{c}\text { Методы анализа } \\
\text { агломерационного } \\
\text { взаимодействия городов }\end{array}$ & Достоинства & Недостатки & $\begin{array}{c}\text { Возможность } \\
\text { применения } \\
\text { методики }\end{array}$ \\
\hline $\begin{array}{l}\text { Метод пространственной кон- } \\
\text { центрации на основе индекса } \\
\text { Тейла }\end{array}$ & $\begin{array}{l}\text { Позволяет выявить неравенство } \\
\text { в развитии городов. Нагляд- } \\
\text { ность }\end{array}$ & $\begin{array}{l}\text { Трудоемкость применения. Не } \\
\text { подходит для анализа моно- } \\
\text { центрических агломераций }\end{array}$ & Нет \\
\hline $\begin{array}{l}\text { Метод исследования регио- } \\
\text { нальной контактно- } \\
\text { гравитацион-ной среды } \\
\text { территории (РКГС) }\end{array}$ & $\begin{array}{l}\text { Способен обеспечить выделе- } \\
\text { ние главных элементов взаимо- } \\
\text { действия между городами; поз- } \\
\text { воляет выявить точки роста. } \\
\text { Относительная новизна мето- } \\
\text { дики; универсальность }\end{array}$ & $\begin{array}{l}\text { Затруднен расчет взаимодейст- } \\
\text { вия городов в полицентричес- } \\
\text { ких агломерациях }\end{array}$ & Да \\
\hline $\begin{array}{l}\text { Метод комплексной оценки ва- } \\
\text { риации показателей МО на ос- } \\
\text { нове индекса Джини }\end{array}$ & $\begin{array}{l}\text { Дает возможность оценки не- } \\
\text { равномерности распределения } \\
\text { изучаемого признака среди } \\
\text { нескольких городов }\end{array}$ & $\begin{array}{l}\text { Ограниченный функционал } \\
\text { применения; полученные ре- } \\
\text { зультаты не детализируются по } \\
\text { каждому из субъектов исследо- } \\
\text { вания. Устаревший метод }\end{array}$ & Нет \\
\hline $\begin{array}{l}\text { Метод делимитации агломера- } \\
\text { ции на основе транспортных } \\
\text { взаимосвязей между городами }\end{array}$ & $\begin{array}{l}\text { Наглядность; надежность полу- } \\
\text { ченных результатов; неоднок- } \\
\text { ратный положительный опыт } \\
\text { применения методики в оте- } \\
\text { чественных научных исследо- } \\
\text { ваниях; мобильность }\end{array}$ & $\begin{array}{l}\text { Необходимость большого ко- } \\
\text { личества картографических } \\
\text { данных и базовых сведений об } \\
\text { объеме автотранспортного } \\
\text { комплекса ядра агломерации. } \\
\text { Относится к группе базовых } \\
\text { методов }\end{array}$ & Да \\
\hline $\begin{array}{l}\text { Метод исследования взаимо- } \\
\text { действия городов как хозяйст- } \\
\text { вующих субъектов }\end{array}$ & $\begin{array}{l}\text { Инновационность. Применим } \\
\text { для расчета экономического } \\
\text { потенциала малых и средних } \\
\text { городов }\end{array}$ & $\begin{array}{l}\text { Не применим для изучения } \\
\text { взаимосвязи городов в крупных } \\
\text { и крупнейших агломерациях. } \\
\text { Трудоемкость применения }\end{array}$ & Нет \\
\hline
\end{tabular}

Примечание. Составлено автором.

Ростовская городская агломерация на сегодняшний день является крупнейшим центром притяжения экономических ресурсов всего Юга России. Ее территория охватывает 5,8 тыс. км ${ }^{2}$, на которых проживает около 1,8 млн чел.; из них 1,6 млн чел. городского населения (см. рис. 1) [12].

Опорная территория, входящая в зону влияния ядра агломерации, представленного областным центром, включает в себя 10 муниципальных образований, в том числе города Таганрог, Азов, Новочеркасск, Батайск, Аксай. Муниципальные районы, входящие в состав городской агломерации, образуют своеобразный полумесяц вокруг Ростова-на-Дону, простираясь к западу и югу от него вдоль побережья Азовского моря (см. рис. 1). В их пределах расположен 391 сельский населенный пункт.

Ростовская агломерация относится к числу крупнейших моноцентрических урбанистических поселений России, находится в процессе динамичного развития и выступает пристальным объектом изучения специ- алистов уже не первое десятилетие. В ее состав входит ряд крупных транспортных узлов - морские порты международного класca, одна из крупнейших железнодорожных станций, автомобильные магистрали, связывающие Южный и Северо-Кавказский федеральные округа с Центральной Россией и Поволжьем [1, с. 71]. Города, входящие в состав агломерации, отличаются друг от друга не только количественными параметрами (население, транспортная удаленность, инвестиционная активность, бюджетообеспеченность), но и качественными признаками, в первую очередь благодаря своему функциональному назначению. Наиболее наглядно это иллюстрируют показатели развития пяти городов опорной территории агломерации (см. табл. 3).

Расчет степени связанности городов, входящих в состав Ростовской городской агломерации, на основе модели РКГС позволяет констатировать существенный размах показателей, характеризующих их взаимодействие с ядром агломерации (см. рис. 2). 
E.O. Миргородская. Оценка территориально-экономической связанности городов в агломерации

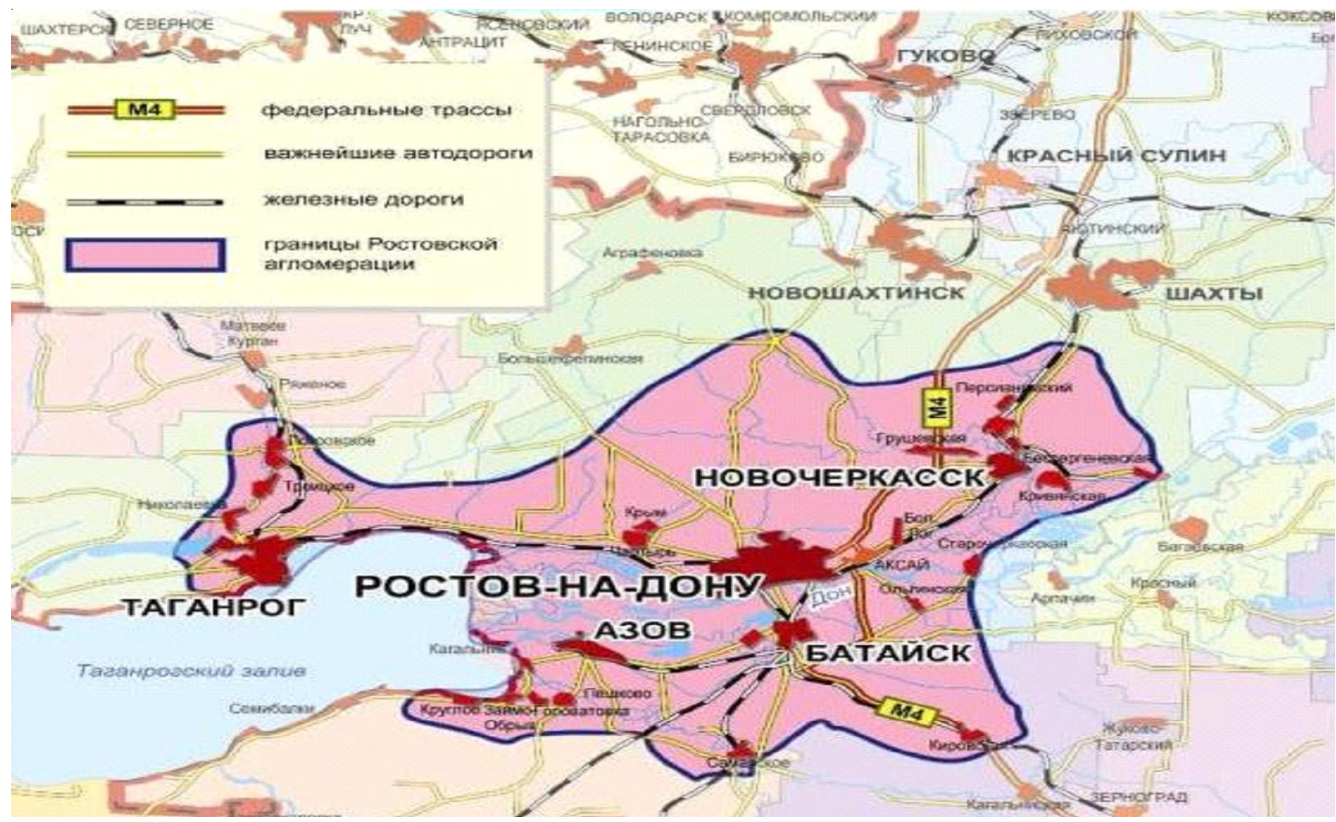

Рис. 1. Пространственная локализация Ростовской агломерации

Примечание. Источник: http://ic.pics.livejournal.com/bredikhinav/20230044/146710/146710_600.jpg.

Таблица 3

Показатели пространственной концентрации городов агломерации Большой Ростов по модели РКГС

\begin{tabular}{|c|c|c|c|c|c|}
\hline Территория & Батайск & Азов & Новочеркасск & Таганрог & Аксай \\
\hline Удаленность от ядра агломерации, км & 15 & 38 & 41 & 77 & 16 \\
\hline Численность городского населения, тыс. чел. & 122 & 82 & 170 & 251 & 44 \\
\hline Число предприятий в городе, ед. & 2175 & 1756 & 4070 & 7090 & 2811 \\
\hline Площадь территории, км² & 77,68 & 67,5 & 128,0 & 95 & 65,7 \\
\hline $\begin{array}{l}\text { Длинна дорог с твердым покрытием на терри- } \\
\text { тории муниципалитета, км }\end{array}$ & 282,3 & 159,8 & 945,0 & 615,7 & 81,4 \\
\hline $\begin{array}{l}\text { Плотность дорог с твердым покрытием на тер- } \\
\text { ритории муниципалитета, км/км }{ }^{2}\end{array}$ & 3,6 & 2,3 & 7,4 & 6,5 & 1,2 \\
\hline Поправочный коэффициент & 1,5 & 1,25 & 1 & 1 & 1,25 \\
\hline Величина РКГС & 11119,9 & 1304,6 & 1338 & 246,3 & 4107,2 \\
\hline
\end{tabular}

Примечание. Составлено и рассчитано по данным: [12; 14].

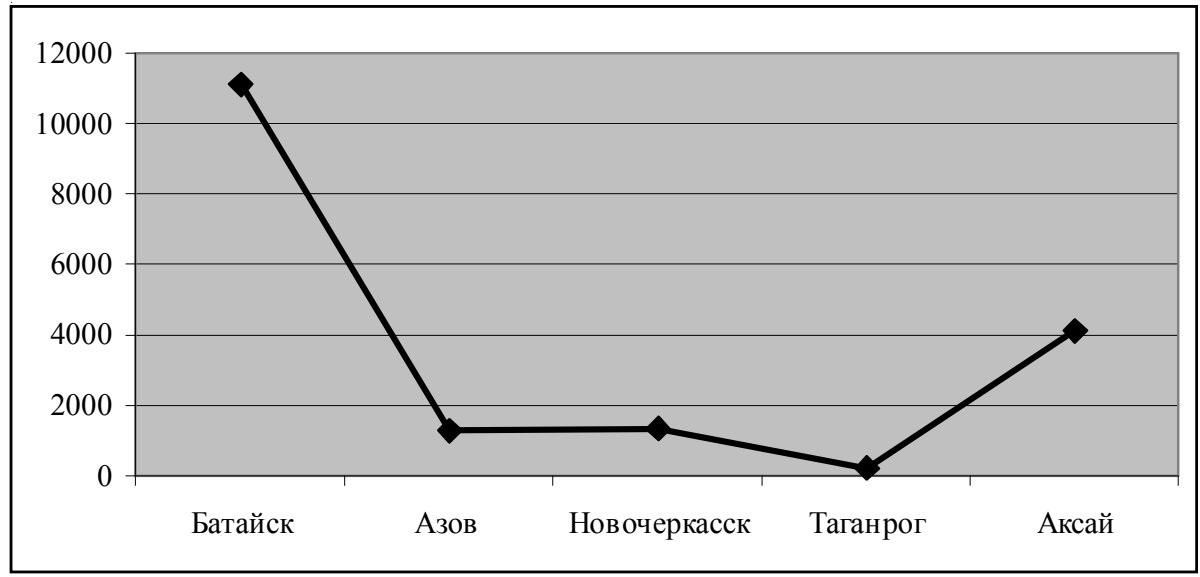

Рис. 2. Распределение городов, входящих в состав Ростовской агломерации, по объему взаимодействия с ядром, ед. величины РКГС 
Наибольшую связь с ядром демонстрируют города Батайск и Аксай, имеющие традиционные, исторически сложившиеся и активно развивающиеся (в силу территориальной близости) экономические связи с Ростовом-на-Дону, являясь его городами-спутниками. Отмечается прямая связь между уровнем дохода населения этих городов и ВРП, производимым ядром агломерации. Применение модели РКГС позволяет выделить Батайск как основной центр притяжения для ядра - город является приоритетной площадкой для развития девелопмента, в частности строительства «спальных» зон агломерации, и размещения промышленных коворкингов. Связанность других городов с ядром агломерации существенно слаба, что объясняется их местоположением на большей удаленности от Ростова-на-Дону и более низкой его транспортной доступностью для жителей.

Для того чтобы скорректировать полученные результаты, необходимо исследовать транспортную инфраструктуру агломерации как коммуникативную основу взаимодействия между ядром и муниципалитетами опорной территории. Для этого воспользуемся методом делимитации агломерации на основе транспортных взаимосвязей между городами.

Транспортная инфраструктура Ростовской агломерации - это важнейший элемент, опосредующий взаимодействие между городами, выступающий ее опорным каркасом [10]. Транспортные узлы агломерации (прежде всего Ростов-на-Дону и Батайск в сухопутном отношении, Таганрог в силу важности его транзитных функций, в том числе и в морском сообщении) служат фокусами, посредством которых ядро агломерации получает ресурсы и распределяет капитал опорной территории, в том числе важнейшую его часть трудовые ресурсы [1]. Именно поэтому вопрос транспортной доступности в разрезе развитости пассажирского сообщения между городами агломерации имеет приоритетное значение [10]. Анализ объемов перевозок пассажиров межу городами агломерации отражает суть взаимодействия между ними и позволяет выявить степень влияния ядра на муниципалитеты опорной территории.

Ростовская агломерация использует преимущества своего выгодного транспортно- географического положения на одной из главных радиальных транспортных осей страны автомобильной дороги федерального значения M4 «Дон» Москва - Воронеж - Ростов-наДону - Краснодар - Новороссийск и дублирующей ее железной дороги Москва - Ростов-на-Дону - Баку. Эти транспортные магистрали образуют основную планировочную ось, вдоль которой расположены ведущие крупные города и промышленные центры Ростовской области, в том числе агломерации.

В то же время локализация транспортной инфраструктуры, размещение производительных сил и система расселения области характеризуются значительной пространственной дифференциацией, в том числе и в пределах Ростовской агломерации. Особенно существенна неравномерность развития транспортной инфраструктуры. Транспортную доступность муниципалитетов в пределах агломерации можно выявить посредством рассмотрения локализации транспортных узлов и интенсивности пассажирского сообщения между ними, поскольку именно общественный транспорт, в отличие от личных транспортных средств, имеет устойчивый график движения и стабильные маршруты.

Анализ имеющихся данных позволяет оценить пространственную дифференциацию плотности транспортного потока, связывающего города агломерации. В движении пригородных пассажирских электропоездов (см. табл. 4) ведущее значение принадлежит направлению Ростов-на-Дону - Таганрог, где количество составов достигает 13 пар в сутки. От Таганрога в направлении п. Матвеево-Курган отправляется только 6 электричек, сформированных непосредственно в Таганроге; аналогичное количество маршрутов движения электропоездов действует и в направлении Ростов-на-Дону - Азов. Несколько больше составов формируется в направлении станций Староминская и Кущевская (соответственно - 9 и 8 электричек в сутки), расположенных на территории Краснодарского края, но обслуживающих своим маршрутом транспортные связи южной периферии агломерации. Столь относительно высокое количество составов, особенно в направлении ст. Староминской, вызвано практически полным отсутствием маршрутных сообщений других видов обществен- 
E.O. Миргородская. Оценка территориально-экономической связанности городов в агломерации

Таблица 4

Схема железнодорожного взаимодействия городов Ростовской агломерации

\begin{tabular}{|c|l|c|c|c|c|}
\hline № & \multicolumn{1}{|l|}{ Полное наименование маршрута } & $\begin{array}{c}\text { Конечная точка } \\
\text { агломерации, } \\
\text { которую пересекает } \\
\text { маршрут }\end{array}$ & $\begin{array}{c}\text { Среднее время } \\
\text { в пути до ко- } \\
\text { нечной точки } \\
\text { агломерации, ч }\end{array}$ & $\begin{array}{c}\text { Расстояние } \\
\text { между Ростовом } \\
\text { и конечной точ- } \\
\text { кой агломе- } \\
\text { рации, км }\end{array}$ & $\begin{array}{c}\text { Количество } \\
\text { составов }\end{array}$ \\
\hline 1 & Ростов-на-Дону - Таганрог & г. Таганрог & 1,2 & 77 & 13 \\
\hline 2 & Ростов-на-Дону - Азов & Г. Азов & 1,05 & 38 & 6 \\
\hline 3 & $\begin{array}{l}\text { Ростов-на-Дону - Староминская } \\
\text { (пересекает границу Краснодарс- } \\
\text { кого края) }\end{array}$ & $\begin{array}{l}\text { х. Еремеевка } \\
\text { (ст. } 1382 \text { км) }\end{array}$ & 1 & 52 & 8 \\
\hline 4 & $\begin{array}{l}\text { Ростов-на-Дону - Кущевская } \\
\text { (пересекает границу Краснодарс- } \\
\text { кого края) }\end{array}$ & $\begin{array}{l}\text { с. Самарское } \\
\text { (ст. Каяла) }\end{array}$ & 1,02 & 40 & \\
\hline 5 & Ростов-на-Дону - Новочеркасск & г. Новочеркасск & 1,15 & 41 & 5 \\
\hline 6 & Ростов-на-Дону -Сальск & ст. Кагальницкая & 1,09 & 55 & 3 \\
\hline
\end{tabular}

Примечание. Составлено по данным ОАО РЖД: [13].

ного транспорта с южным вектором Ростовской агломерации, выходящим к границе с Краснодарским краем. Сравнительно невысокой остается интенсивность пассажирского сообщения по направлениям Ростов-наДону - Новочеркасск и Ростов-на-Дону Сальск - 5 и 3 единиц состава соответственно. Причем в последнем направлении отсутствует электрификация железнодорожных путей, что приводит к необходимости использования тепловозной тяги и стандартных пассажирских составов, но из-за повышенного количества остановок снижается скорость движения и увеличивается продолжительность рейса, что негативно отражается на интенсивности транспортного сообщения с ядром агломерации.

Обобщая полученные данные, можно констатировать, что Ростовская агломерация имеет развитую сеть железнодорожного сообщения, а транспортная доступность городов, в том числе крайних по расположению муниципальных образований агломерации, не превышает 1,5 часов, что в целом обусловливает высокую мобильность населения в пределах агломерации. Железнодорожная сеть агломерации имеет три направления - северное, западное и южное (юго-восточное), представленных в виде шести радиально расположенных маршрутов движения, замыкающихся на ядре агломерации - г. Ростове-на-Дону. Однако основными точками железнодорожной транспортной сети агломерации являются другие муниципальные образования - прежде всего города Батайск и Таганрог. Интенсив- ность движения в среднем за год составляет 44 состава в сутки.

Другой составляющей транспортного взаимодействия между городами агломерации выступают регулярное автобусное сообщение. По территории агломерации проходят две федеральные магистрали: M23 направления Ростов-на-Дону - Таганрог и М4 Ростовна-Дону - Шахты. Основным вектором автобусного сообщения между городами агломерации является федеральная трасса М4 «Дон», в направлении Ростов-на-Дону - Шахты (196 единиц автобусов в одном направлении в сутки), из них в направлении г. Новочеркасска ежедневно выдвигается до 68 единиц, а без остановок в Новочеркасске по направлению к г. Шахты - остальные 128 единиц [11].

Более низкую интенсивность транспортного обслуживания имеет маршрут Ростовна-Дону - Азов (85 единиц автобусов общественного пользования в одном направлении в сутки) и Ростов-на-Дону - Самбек (73 единицы в одну сторону), от которого 63 маршрута направляются на Таганрог и 10 на Матвеево-Курган. Из других линий маршрутного движения общественного автопарка в пределах агломерации необходимо отметить направление Ростов-на-Дону - Кагальницкая (19 единиц), Новочеркасск - х. Персиановский (12 единиц). Кроме того, имеются 4 маршрута автобусов из Ростова-на-Дону в слободу Радионо-Несветайскую (административный центр одноименного муниципального района в составе агломерации). В итоге общая численность рейсов автобус- 
ного парка в пределах агломерации составляет 354 единицы [11].

Анализ пассажирского сообщения посредством автомобильного транспорта показал относительное несовершенство транспортной системы агломерации. Наблюдается асимметрия распределения автобусного парка по пассажирским линиям: основная загруженность (196 единиц транспортных средств) приходится на северное направление агломерации, в то время как южное направление (в с. Самарское) и юго-восточное направление (в ст. Кагальницкую) практически лишены автобусного сообщения. Данная пространственная диспропорция не может оказать существенного влияния на развитие агломерации в целом, поскольку все города, входящие в состав Ростовской агломерации, обеспечены автобусным сообщением в полной мере.

Озвученная проблема неравномерного распространения автобусного сообщения в пределах агломерации касается крупных сельских поселений и практически всех периферийных частей агломерации. Не оказывая влияния на функционирование агломерации в целом, подобная диспропорция, тем не менее, напрямую детерминирует степень развития связей между поселениями в среднесрочном периоде, так как население ряда муниципальных образований лишено возможности интегрироваться в агломерационное поле. В наибольшей степени эта проблема затронула значительные северные и центральные части Родионо-Несветайского и Октябрьского районов. Данная ситуация может привести к отдалению этих территорий от Ростовской агломерации и их тяготению к другому социально-экономическому центру области - городу Шахты, который формирует Шахтинскую конурбацию.

Оценка движения речного транспорта в данном исследовании не производилась из-за его сезонности, низкого уровня скоростного движения: во все населенные пункты Ростовской агломерации, находящиеся на водных артериях, другими видами транспорта можно попасть в 1,5-2 раза быстрее, чем речным сообщением. Речной транспорт фактически используется лишь как элемент туристической сферы региона, удовлетворяя туристические потребности гостей агломерации в крат- ковременных путешествиях по реке Дон, либо как элемент рекреационного комплекса для населения агломерации.

Резюмируя анализ транспортного взаимодействия городов, входящих в состав Ростовской агломерации, составим их рейтинг на основе транспортного взаимодействия, используя для оценки пятибалльную систему. Полученные результаты рейтинга городов агломерации на основе транспортного взаимодействия позволяют провести ранжирование муниципалитетов следующим образом:

1-е место - г. Батайск. Он занимает лидирующую позицию в виду важности и значимости транспортных артерий, расположенных на территории муниципалитета. Здесь происходит распределение транспортного потока, движущегося по железной дороге из ядра агломерации в южном направлении (в г. Азов, с. Самарское и ст. Кагальницкую). В пределах города расположен крупный железнодорожный узел с функцией формирования грузовых составов; вдоль границ муниципального образования проходит федеральная трасса M4 и осуществляется автомобильная связь с г. Азовом.

2-е место - г. Таганрог. В направлении города из центра агломерации выходит наибольшее количество железнодорожного пассажирского транспорта; вдоль границ Таганрога проходит федеральная трасса М23 и железнодорожный путь, связывающие Россию и Украину, что до последнего времени позволяло осуществлять активный товарооборот с соседним государством. На территории города находится международный морской порт, что также придает важность его транспортной функции.

3-е место - г. Азов, чья связь с городами агломерации представлена как железнодорожным, так и автомобильным транспортом в полной мере, при этом на территории города имеется международный морской торговый порт, позволяющий проводить суда типа «река - море» вверх по Дону или с выходом в Азовское море.

4-е место - г. Новочеркасск, в направлении которого выдвигается наибольшее число автобусных маршрутов, а в нескольких километрах от границ города проходит федеральная трасса M4. 
5-е место - г. Аксай. Располагаясь в 15 км от ядра агломерации, Аксай имеет устойчивые связи с центром; однако они почти полностью сфокусированы в направлении Ростова-на-Дону, который и обслуживает его транспортное сообщение. На основе этого Аксай можно рассматривать лишь как городспутник центра агломерации, не имеющий самостоятельного места в иерархии городов агломерации.

Таким образом, транспортное взаимодействие городов Ростовской городской агломерации является стабильным и вполне удовлетворяет потребности населения этих городов. Однако существует асимметрия между транспортной доступностью городов и остальных административно-территориальных единиц, входящих в состав агломерации, к которым относятся крупные сельские поселения и практически вся периферия опорной территории агломерации.

В качестве еще одного важного параметpa, отражающего взаимосвязи городов Ростовской агломерации, рассмотрим дифференциацию муниципалитетов по цене жилья. Как известно, стоимость жилья (особенно в административных центрах федеральных округов) может значительно отличаться от стоимости эквивалентного жилья за пределами центров, к примеру, в соседнем муниципалитете более низкого ранга. В качестве индикатора нашего исследования была отобрана стоимость стандартной двухкомнатной квартиры площадью не более $60 \mathrm{~m}^{2}$ в городах Ростовской агломерации по состоянию на 2017 г. (табл. 5). Этот тип квартир был выбран как наиболее популярный вид жилья в стране.
Анализ актуального состояния рынка недвижимости агломерации дополняет вывод о диспропорции в развитии муниципалитетов в сравнении с Ростовом-на-Дону в 1,5-2 раза, установленный выше на основе распределения пассажиропотока между городами агломерации.

Обобщая полученные результаты по рассмотренным индикаторам, представим итоговую типологию городов Ростовской городской агломерации по степени связей между ними (для этого был использован рейтинг городов, входящих в состав агломерации, составленный на основе их экономической и пространственной связи с центром - г. Ростовом-наДону) и осуществим их рейтинговую оценку (см. табл. 6). Ее результат позволяет определить в качестве наиболее перспективного муниципалитета в развитии Ростовской агломерации город Батайск. В нем расположен один из крупнейших в России логистических узлов, представленный крупной железнодорожной станцией и пересечением автомобильных дорог. Город имеет обширную промышленную и социально-культурную базу благодаря наличию предприятий с ярко выраженной экспортной направленностью в своей деятельности. Хотя в условиях развития экономики страны под влиянием санкций со стороны развитых стран мира, прибыль таких предприятий от внешнеэкономических отношений снижена, но потенциал своей производственной деятельности они сохраняют и реализуют в направлении обеспечения отечественного рынка.

Аналогом Батайску благодаря сверхблизкому расстоянию от ядра агломерации (не

Таблииа 5

\section{Средняя стоимость типовой двухкомнатной квартиры в разрезе городов Ростовской агломерации в 2017 г.}

\begin{tabular}{|c|c|c|c|c|c|c|}
\hline \multirow{2}{*}{ Показатель } & \multicolumn{5}{|c|}{ Города опорной территории агломерации } & \multirow{2}{*}{$\begin{array}{c}\begin{array}{c}\text { Ядро } \\
\text { агломерации }\end{array} \\
\text { Ростов-на-Дону }\end{array}$} \\
\hline & Азов & Аксай & Новочеркасск & Таганрог & Батайск & \\
\hline $\begin{array}{l}\text { Цена двухкомнатной квартиры, } \\
\text { тыс. руб. }\end{array}$ & 2700 & 2997 & 1915 & 2104 & 2544 & 3575 \\
\hline Цена за м², тыс. руб. & 45 & 50 & 32 & 35 & 42 & 60 \\
\hline $\begin{array}{l}\text { Отношение стоимости квартиры } \\
\text { на территории центра и опорной } \\
\text { территории, \% }\end{array}$ & 76 & 84 & 54 & 59 & 71 & 100 \\
\hline
\end{tabular}

Примечание. Составлено по данным Ростовстата (URL: http://rostov.gks.ru/rostov/ru/municipal_statistics/ list_of_municipalities/). 
Балльная оценка индикаторов территориально-экономической связанности городов Ростовской городской агломерации

\begin{tabular}{|l|c|c|c|c|c|}
\hline \multicolumn{1}{|c|}{ Города } & Батайск & Аксай & Новочеркасск & Азов & Таганрог \\
\hline Ранги городов по объему взаимодействия с центром & 5 & 4 & 3 & 2 & 1 \\
\hline Ранги городов по динамике развития & 5 & 3 & 2 & 1 & 4 \\
\hline $\begin{array}{l}\text { Ранги городов по социально-экономическому сос- } \\
\text { тоянию }\end{array}$ & 1 & 2 & 3 & 5 & 4 \\
\hline $\begin{array}{l}\text { Ранги городов по транспортному взаимодействию } \\
\text { между ними }\end{array}$ & 5 & 1 & 2 & 3 & 4 \\
\hline Суммарное количество баллов & 16 & 10 & 9 & 11 & 13 \\
\hline $\begin{array}{l}\text { Итоговое место в рейтинге городов, входящих в аг- } \\
\text { ломерацию }\end{array}$ & I & IV & V & III & II \\
\hline
\end{tabular}

Примечание. Составлено автором.

более 15 км) выступает город Аксай как второй спутник Ростова-на-Дону. Однако Аксай позиционируется преимущественно как площадка для строительства жилья, в то время как Батайск реализует также функции выгодно расположенного транспортного узла и промышленного центра, на территории которого перспективно развитие обрабатывающих производств различного профиля.

Вторую позицию в рейтинге городов Ростовской агломерации занимает Таганрог. Он является одним из ведущих промышленных центров Ростовской области, уступая по уровню производства готовой промышленной продукции лишь Ростову-на-Дону. Доля города в общем объеме промышленного производства Ростовской области составляет $15 \%$, значителен и собственный трудовой потенциал (162 тыс. чел.). Предприятия Таганрога активно развивают инновационные производства имеется около 40 приоритетных инвестиционных проектов, однако большинство из них являются узконаправленными (к примеру, разработка программных модулей для стыковки имитаторов гидроакустической аппаратуры с тренажерами), поэтому им достаточно сложно достичь необходимого уровня капитализации. Таганрог обладает относительно развитой транспортной инфраструктурой, охватывающей практически все виды транспорта, включая воздушный (аэропорт присутствует в городской черте и будет являться дублером нового аэропортового комплекса Платовский, находящегося к северо-востоку от Ростована-Дону в Аксайском районе). Город следует рассматривать как удобную инновационную площадку, на базе которой возможен запуск некого подобия технограда, нацеленного на полный цикл венчурного бизнеса - от разработки промышленного образца до его внедрения в производство. Для этого необходимо сменить вектор научных исследований, проводимых в научных и образовательных учреждениях региона, на более прикладную и коммерчески обоснованную сферу, а именно на инновации машиностроительного и сельскохозяйственных секторов экономики, востребованных на рынке.

Основу экономики города Азова в составе Ростовской агломерации составляют обрабатывающие производства. На территории города работают 33 крупных и средних промышленных предприятия, имеется международный морской порт. Азов отличается высоким темпом роста инвестиций в основной капитал организаций, что позволяет поддерживать стабильный объем доходов местного бюджета и способствует росту прибыли организаций. В настоящий момент на территории города формируется обширная по территории Юго-Восточная промышленная зона, это опосредует столь высокий уровень инвестиций в основной капитал муниципалитета и указывает на его существенную инвестиционную привлекательность. Азов обладает значительными предпосылками для развития пищевой промышленности: в промышленной зоне города расположено одно из крупнейших предприятий пищевого сектора экономики юга страны завод компании «Coca-Cola HBC Russia». Помимо него в городе также действуют кондитерская фабрика «Азовчанка», завод рыбных консервов, ОАО «Азовский хлеб» и комбинат хлебопродуктов, предприятие по произ- 
водству чипсов и экструдированной продукции (сухарики, хлебцы) ООО «Фрито Лей Мануфактуринг», ООО ПКФ «Проксима», специализирующееся на выпуске мороженного.

Несмотря на прямое территориальное соседство с ядром агломерации, город Аксай занял четвертое место в составленном рейтинге. Данное городское поселение испытывает недостаток как в трудовых ресурсах, так и в капитале, не имея уникальных производств (в отличие от Батайска). Город фактически превращается в своеобразный «спальный» район Ростова-на-Дону, куда возвращаются жители после трудовой деятельности на территории ядра. Однако анализ, проведенный на основе пространственной контактно-гравитационной среды территории (РКГС), показал, что город отличается высоким объемом взаимодействия с ядром, что дает основание, по нашему мнению, рассматривать Аксай не только как площадку для строительства жилья, но и как рекреационную зону и важный транспортный узел, с помощью которого во3можно разгрузить транспортные потоки в юговосточном направлении агломерации.

Последнее место в рейтинге городов Ростовской агломерации принадлежит Новочеркасску. Он занимает третье место по количеству населения в агломерации, уступая лишь Ростову и Таганрогу. Градообразующими предприятиями города являются ГРЭС, которая обеспечивает значительную часть Юго-Западного района области электричеством, уникальный электровозостроительный завод по производству пассажирских и грузовых электровозов, другие предприятия машиностроения. В своем развитии город испытывает сильнейшую зависимость от этих градообразующих предприятий, спрос на продукцию которых является неэластичным. В связи с этим необходима диверсификация отраслей экономики города, так как в настоящее время его потенциал развития ограничен.

Таким образом, механизм взаимодействия городов агломерации выражается в организационных и институциональных пространственно-экономических связях между городскими территориями. Они обусловлены социоприродно-экономическими факторами их локализации и функционирования. Учет степени территориально-экономических связей необ- ходим при решении теоретических и практических задач, связанных с особенностями взаимодействия городов в рамках агломерации, влиянием агломерации на развитие регионального экономического пространства, а также выработкой и реализацией предложений по дальнейшему развитию городских агломераций в направлении сбалансированного развития ее структурных элементов.

\section{СПИСОК ЛИТЕРАТУРЫ}

1. Атлас социально-экономического развития Юга России / А. Ю. Архипов, Е. М. Афонина, Н. В. Гонтарь [и др.]. - М. : Вузовская книга, 2011. $144 \mathrm{c}$.

2. Баранов, С. В. Комплексная оценка социально-экономического развития городов и районов Мурманской области / С. В. Баранов // Вестник Кольского научного центра РАН. - 2011. - № 4 - С. 46-51.

3. Волчкова, И. В. Теория и практика управления развитием агломераций : монография / И. В. Волчкова, Н. Н. Минаев. - Томск : ТГАСУ, 2014. - С. 234.

4. Делимитация и расчет развитости городских агломераций. Лекция 3 // Национальный исследовательский университет «Высшая школа экономики». - Электрон. текстовые дан. - Режим доступа: http://www.hse.ru/data/228/116.ppt. - Загл. с экрана.

5. Коломак, Е. А. Исследование агломерационных процессов на территории Новосибирской области / Е. А. Коломак // Регион: экономика и социология. - 2013. - № 3 - С. 239-259.

6. Кутовой, С. И. Взаимодействие городов как механизм развития регионального экономического пространства : дис. ... канд. экон. наук / Кутовой Святослав Игоревич. - Ставрополь, 2014. -233 с.

7. Лаппо, Г. М. Агломерации России в XXI веке / Г. М. Лаппо, П. М. Полян, Т. И. Селиванова // Вестник Фонда регионального развития Иркутской области. - 2007. - № 1. - С. 45-52.

8. Лаппо, Г. М. География городов / Г. М. Лаппо. - М. : Владос, 1997. - 481 с.

9. Меринов, Ю. Н. Делимитация Ростовской агломерации / Ю. Н. Меринов, Ю. Ю. Меринова // Науковедение : интернет-журн. - 2014. - № 6. Электрон. текстовые дан. - Режим доступа: http:// naukovedenie.ru/PDF/84EVN614.pdf. - Загл. с экрана.

10. Миргородская, Е. О. Транспорт и социально-экономическое развитие крупного города: методология взаимовлияния / Е. О. Миргородская // Экономика и предпринимательство. - 2016. - № 12-4. C. 327-335.

11. Расписание движения по ст. Ростов - Главный автовокзал // ПАО «Донавтовокзал» : офиц. 
сайт. - Электрон. текстовые дан. - Режим доступа: http://www.donavto.ru/index.php?option=com content\&view $=$ article \&id $=57 \&$ Itemid $=37 .-$ Загл. с экрана.

12. Ростовская область в цифрах 2015 : стат. сб. - Ростов н/Д : Ростовстат, 2016. - 736 с.

13. Северо-Кавказская железная дорога // ОАО «РЖД» : офиц. сайт. - Электрон. текстовые дан. Режим доступа: http://skzd.rzd.ru/ - Загл. с экрана.

14. Сравнительные показатели социально-экономического положения городских округов и муниципальных районов Ростовской области - 2015 : стат. сб. - Ростов н/Д : Ростовстат, 2016. - 392 с.

\section{REFERENCES}

1. Arkhipov A.Yu., Afonina E.M., Gontar N.V., et al. Atlas sotsialno-ekonomicheskogo razvitiya Yuga Rossii [Atlas of Socio-Economic Development of the South of Russia]. Moscow, Vuzovskaya kniga Publ., 2011. 144 p.

2. Baranov S.V. Kompleksnaya otsenka sotsialnoekonomicheskogo razvitiya gorodov i rayonov Murmanskoy oblasti [Comprehensive Assessment of Social and Economic Development of Cities and Districts of the Murmansk Region]. Vestnik Kolskogo nauchnogo tsentra RAN, 2011, no. 4, pp. 46-51.

3. Volchkova I.V., Minaev N.N. Teoriya $i$ praktika upravleniya razvitiem aglomeratsiy: monografiya [Theory and Practice of Management of Development of Agglomerations. Monograph]. Tomsk, TGASUPubl., 2014. 234 p.

4. Delimitatsiya i raschet razvitosti gorodskikh aglomeratsiy. Lektsiya 3 [Delimitation and Calculation of the Development of Urban Agglomerations. Lecture 3]. URL: http://www.hse.ru/data/228/116.

5. Kolomak E.A. Issledovanie aglomeratsionnykh protsessov na territorii Novosibirskoyoblasti [Study of the agglomeration process on the territory of the Novosibirsk region]. Region: ekonomika i sotsiologiya, 2013, no. 3, pp. 239-259.
6. Kutovoy S.I. Vzaimodeystvie gorodov kak mekhanizm razvitiya regionalnogo ekonomicheskogo prostranstva: dis. ... kand. ekon. nauk [Interaction of Cities as a Mechanism for Development of a Regional Economic Space. Cand. econ. sci. diss.]. Stavropol, 2014. $233 \mathrm{p}$.

7. Lappo G.M., Polyan P.M., Selivanova T.I. Aglomeratsii Rossii v XXI veke [Agglomerations of Russia in the $21^{\text {st }}$ Century]. Vestnik Fonda regionalnogo razvitiya Irkutskoy oblasti, 2007, no 1. pp. 45-52.

8. Lappo G.M. Geografiya gorodov [Urban Geography]. Moscow, Vlados Publ., 1997. 481 p.

9. Merinov Yu.N., Merinova Yu.Yu. Delimitatsiya Rostovskoy aglomeratsii [Delimitation of the Rostov Agglomeration]. Naukovedenie: internet-zhurnal, 2014, no. 6. URL: http:// naukovedenie.ru/PDF/84EVN614.pdf. (accessed September 28, 2017).

10. Mirgorodskaya E.O. Transport i sotsialnoekonomicheskoe razvitie krupnogo goroda: metodologiya vzaimovliyaniya [Transport and SocioEconomic Development of a Major City: the Methodology of Mutual Influence]. Ekonomika $i$ predprinimatelstvo, 2016, no. 12-4, pp. 327-335.

11. Raspisanie dvizheniya po st. Rostov-Glavnyy avtovokzal [The Schedule of Buses to Rostov - Main Bus Station]. URL: http://www.donavto.ru/index.php? option $=$ com_content\&view=article\&id=57\&Itemid=37. (accessed September 27, 2017).

12. Rostovskaya oblast $v$ tsifrakh 2015: stat. sb. [The Rostov Region in Figures 2015: Statistical Database]. Rostov-on-Don, Rostovstat Publ., 2016. 736 p.

13. Severo-Kavkazskaya zheleznaya doroga [North-Caucasian Railway]. URL: http://skzd.rzd.ru/. (accessed September 26, 2017).

14. Sravnitelnye pokazateli sotsialnoekonomicheskogo polozheniya gorodskikh okrugov i munitsipalnykh rayonov Rostovskoy oblasti - 2015: stat. $s$. [Comparative Indicators of the Socio-Economic Situation of Urban Districts and Municipal Districts of the Rostov Region -2015: Statistical Database]. Rostovon-Don, Rostovstat Publ., 2016. 392 p.

\section{Information about the Author}

Elena O. Mirgorodskaya, Doctor of Sciences (Economics), Professor, Head of Department of Economic Theory and Entrepreneurship, Don State Technical University, Sotsialisticheskaya St., 162, 344022 Rostov-on-Don, Russian Federation, emirgorod@mail.ru.

\section{Информация об авторе}

Елена Олеговна Миргородская, доктор экономических наук, профессор, заведующая кафедрой экономической теории и предпринимательства, Донской государственный технический университет, ул. Социалистическая, 162, 344022 г. Ростов-на-Дону, Российская Федерация, emirgorod@mail.ru. 